\title{
Feminist Movements and the Gender Economic Agenda in Latin America
}

\author{
Ana-Laura Rodríguez Gustá and Nancy Madera
}

\begin{abstract}
In Latin America, the Fourth World Conference on Women in Beijing represents a milestone in the history of the feminist and women's movements. Twenty years have passed and despite important achievements in gender equality, for issues of economic equality the results are still meagre and there remains a long road ahead in the fields of employment, access to resources, and social protection for women. Unsurprisingly, it is in economic matters that the feminist and women's movements have renewed their themes and strategies. This article identifies a gender economic agenda that is broad in its transformative scope and in its determination to challenge core aspects of the current economic and social organisation. This broad perspective is a direct legacy of the Beijing Platform for Action but expands a step beyond as it incorporates new challenges for bringing gender justice by questioning the current ways of production and consumption.
\end{abstract}

\section{Introduction}

For Latin America, the Fourth World Conference on Women held in Beijing represents a milestone in the history of the feminist and women's movements, for at least two reasons. Firstly, it has provided legitimacy for gender equality being seen as a key issue for the development and welfare of societies. Secondly, the Beijing Platform for Action (BPfA) has provided an overarching frame for collective mobilisation. Along with the Convention on the Elimination of All Forms of Discrimination against Women (CEDAW) and other regional human rights instruments, the BPfA has proved to be a key discursive tool in the rhetorical battles for advancing debates and interventions on gender (CEPAL 2015). The BPfA conceives the economy as a social process that is, simultaneously, a cause and a consequence of inequalities between women and men. In particular, it states that women should be able to exert power over economic structures in their societies. For this, it calls for including gender concerns in national policies and multilateral programmes.

In the 20 years since Beijing, Latin American societies have experienced a change in political, social and economic conditions. The region has seen a decade of economic growth as well as an expansion in many social services and provisions. Economic growth coupled with pending issues in achieving widespread social and labour inclusion (Martínez Franzoni and Sánchez-Ancochea 2014), prove a new terrain for reshaping the equality agenda and crafting new policies.

Despite important achievements in gender equality, however, progress has been slow, heterogeneous and mostly confined to legal and institutional matters (CEPAL 2015). In issues of economic equality compared to, for instance, political representation in formal institutions - the results are still meagre and a long road lies ahead in the fields of employment, access to resources and social protection.

Not surprisingly, then, it is on economic issues that Latin American feminist and women's movements have renewed their strategies (see, for example, Celiberti and Vargas 2003; Valdivieso 2014). This article identifies a gender economic agenda that is broad in its transformative scope and in its determination to challenge core aspects of the current economic and social organisation. This broad perspective is a direct legacy of the BPfA, but expands a step beyond as it incorporates new challenges to pursue gender justice. This agenda also envisions new ways of production and consumption (Pérez Orozco 2012).

The articulation and expansion of the gender economic agenda has been nourished by different strands of feminist and women's movements, gaining depth from dialogue with other social movements (Cumés and Cu 2012; Rousseau 2011; Gargallo 2009).

IDS Bulletin Volume 46 Number 4 July 2015 (c) 2015 The Authors. IDS Bulletin (C) 2015 Institute of Development Studies

Published by John Wiley \& Sons Ltd, 9600 Garsington Road, Oxford OX4 2DQ, UK and 350 Main Street, Malden, MA 02148, USA 
While the BPfA put forth the idea of women's economic autonomy, current perspectives on the economy incorporate both economic and social rights as well as the institutional foundations of the economic system as targets of social action.

In this article, we examine the issues that comprise the gender economic agenda that feminist organisations are currently pushing forth across the region. The empirical material was gathered systematically by means of 70 in-depth interviews with a range of activists in 18 Latin American countries. This material shows that the gender economic agenda is not confined to work and employment, as substantive as these topics are, and that this agenda also challenges economic rationalisation. In this sense, the agenda goes one step forward from Beijing, a fact which reflects that feminists in the region are committed to transforming gender equality vis-à-vis the overall economic system.

\section{Feminist movements and the gender economic agenda}

'We, feminists, are more sensitive to the autonomy of indigenous people's territories, with access to land, with food sustainability... all these issues have had an impact on us.'

Centro de Estudios de la Mujer, Honduras

'In these last few years there have been the topics of women's work, all the issues related to social protection, the issue of female domestic workers, the problem of care in Brazil - important in the eighties, which underwent a period of stalemate but comes back - and the support for reproductive work are all themes and are central for women's autonomy. I also believe that this entire problem about the economy is stronger, from a perspective of resistance against the development model but also proposing a vision about an alternative economy. I think this is a very interesting issue on the feminist agenda today, very interesting.'

SOS CORPO, Brazil

As these quotations reflect, nowadays, feminist and women's movements in the region have a plethora of issues on their agendas dealing with various aspects of women's work and the economy. These issues include the defence of domestic workers' rights, the demand for an increase in poor women's access to credit, the struggle for peasant women's entitlements to land and the protection of female migrant workers. Usually, actions developed around these topics do not stand alone. Economic demands come intermeshed with efforts to broaden women's autonomy in general. To illustrate, the domestic women's association in Altos del Chiapas, Mexico (Colectivo de Empleadas Domésticas de los Altos del Chiapa), combine a recognition of labour rights and social welfare with a public denunciation of the sexual violence experienced by domestic workers, who are indigenous rural women with few Spanish language skills. The National Confederation of Workers in Agriculture (Confederação Nacional dos Trabalhadores na Agricultura, CONTAG) in Brazil also combine work on several rights simultaneously. The well-known mobilisation March of the Marguerites (Marcha Das Maragaridas) covers a wide platform including topics such as women's access to land and training, the expansion of the welfare system for rural women workers, the full exercise of sexual and reproductive rights (including legal and safe abortion), and the prevention and eradication of violence against women.

The economic gender agenda does not confine itself to rights-based issues. Certainly, these are very important topics that refer to the regulation of women's work and employment, their access to economic resources of all sorts (credit, land, training, among others), and their benefits from welfare provisions. Yet, if anything, in defending social and economic rights, women and feminist movements also articulate and advance a larger transformative agenda that directly questions the pillars of capitalism in general and the conditions of exploitation and subordination associated with them. Framed in this way, feminist and women's movements strive to dismantle two basic institutions of capitalism: the sexual division of labour and the centrality of the market as the mechanism for the creation and distribution of wealth, with all their consequences on the social, economic, cultural and political organisation of human life and nature.

Women's movements in the region have been active critics of neoliberal globalisation, market reforms and the shrinking of welfare services (Molyneux 1998). Yet, currently they hold a much broader critical view of development models: the entire capitalist mode of production and consumption is at stake for its inability to care for the reproduction of life, in more general terms. This agenda is reflected in various collective strategies for mobilisation and contestation. Women's movements reject extractivism (such as open-cut mining and fracking), denounce the exploitation of natural resources (forest, land, water), and fight against new forms of economic colonialism, which, for 
- Domestic workers' labour rights, including welfare rights

- Migrant female workers' rights

- Low-income women's access to social protection

- Women's access to natural and economic resources (including land)

- Care facilities and infrastructure

Minimum wage regulations
- Food sovereignty

- Social economy

- Fair trade

- Development sovereignty

- Environmental justice

- Public goods

Source Authors' own based upon in-depth interview material. ${ }^{3}$

the most part, imply authoritarian practices and forced displacement of vulnerable groups. In Costa Rica, the feminist movement played an active role in rejecting the Central America Free Trade Agreement (CAFTA) with the United States in 2009, stating that it introduced neocolonial relations, and also deepened the 'feminisation of poverty' (Facio 2007). The struggle against CAFTA provided a critical conjuncture for articulating efforts and advancing new ideas about society, the state and the market. As an activist from Mesoamerican Women in Resistance for a Worthy Life asserts, they hold:

an ethical resistance (from our values); political (due to our way of understanding power and thinking that we have to create a new form of power, not distribute that available); epistemological (due to our way of thinking, of producing knowledge, because we recognise women's knowledge raising from the care of life), economic (because we understand that we have to work less, we have to de-sacralise money, that we are not poor but impoverished) (Torres 2013).

In Brazil, feminist organisations (such as SOS Corpo and Sempreviva Organização Feminista (SOF), to name just a few) and networks (like Rede Economia e Feminismo), promote food sovereignty and support expressions of social economy to forge more concrete alternatives. In Honduras, feminist collectives are immersed in struggling against the 'model city' (Zone for Employment and Economic Development), which resurrects an economy of enclaves, wherein the nation-state abandons its sovereignty, and its fate is the construction of private cities reigned over by multinational firms (Sagot 2014).

In other words, the economic gender agenda in the region touches upon redistribution issues, in Fraser's terms (1997, 2000), but it also poses questions about the current fabric of economic life itself. Under the term 'sustainability of life', women's movements seek to defend the deployment of natural resources, the use of the territory and food sovereignty. The Final Declaration of the XIII Latin American and the Caribbean Encounter, held in November 2014, reflects the wide scope of the gender economic agenda:

The reflections about the Sustainability of life make it evident that there exists an interrelation between capitalism, heteropatriarchy and coloniality, which impacts upon women. That the way of sustaining life has been resolved with the 
exploitation of women's labour in favour of the accumulation of capitalist markets, and not in favour of the needs of life. That in this advanced stage of an extractive and predator capitalism, the sustainability of life in the planet is also threatened, which calls into question the dominant modes of consumption and production. ${ }^{1}$

In the words of a Uruguayan activist from the collective Cotidiano Mujer, the gender economic agenda is not confined to work and employment as substantive as these topics are - but increasingly includes broader matters. In her own words:

\section{Feminist economists start to lay out a dimension of analysis that is not so much related to the axis capital/ work but to a broader dimension that touches upon all, all spheres of life, and upon the sexual division of labour such as the feminist contribution and questioning of the whole idea of male citizenship, heterosexual superiority, and autonomous and without needs of care as the classic paradigm of citizenship. ${ }^{2}$}

This agenda challenges economic rationalisation. Gender relations are a means for and a result of transforming use value into exchange value. As such, the current logic of capital accumulation cannot be disentangled from the construction of unequal gender relations.

In short, when it comes to economic issues, this gender agenda is an intermingling of diverse yet convergent themes, dealing with economic and welfare regulation but also with the very institutional foundations of capitalism (see Table 1). Hence, by bringing forth and mixing these themes in an overarching perspective for informing their collective actions, Latin American feminist and women's movements stubbornly refuse to give up on the idea of a social economy (or moral economy, as per Thompson 1971), in which women have rights that take precedence over the functioning of market exchanges.

This agenda is not novel either to feminism or to women's social movements. In fact, feminists have, for a long time, argued that the social division of labour under capitalism relegates women to subordinate positions and that market-based projects undermine human wellbeing in all of its dimensions. Feminists have supported the introduction of reforms premised on social and economic equality and universal social provision (Espino 2012). Additionally, they have joined the anti-globalisation movement with other social actors in search of social and economic fairness. Still, we argue that the way this agenda is being articulated, put forth and expanded appears to be a more recent phenomenon in the region, as several activists have suggested.

Throughout the region, the historically dominant themes for feminist movements have been violence against women (in all forms), sexual and reproductive rights (particularly decriminalisation of abortion) and social and political participation and decisionmaking. Yet, the economic agenda is increasingly becoming part of these mainstream issues.

Interestingly, the framing process is not simply one of 'add and stir' more themes into the agenda. On the contrary, these economic themes interact with the other claims within the larger intellectual feminist space. A mix of issues is becoming the norm, which is an articulation that movements are able to reach by employing methodologies such as popular education, ample debate and self-organisation.

Regional networks of civil society organisations play a key role in pushing forth the feminist economic critique to development. These regional actors include historic feminists (feministas históricas), and rural, indigenous and peasant female activists, many of whom identify with feminist claims. Well-known regional networks include the Latin American Network of Women Transforming the Economy (REMTE), ${ }^{4}$ the Popular Education Network among Women of Latin America and the Caribbean (REPEM ), ${ }^{5}$ Marcosur Feminist Articulation, and Mesoamerican Women in Resistance for a Worthy Life. ${ }^{6}$ The political discourses of these regional actors converge into an emancipatory framework.

The gender economic agenda is, therefore, a transnational construct thanks to the ties and spaces of debate that feminists and women's movements have constructed between themselves and with other social movements. Furthermore, as the women's movement is a global movement, the regional economic agenda has benefited from a dialogue with various types of movements worldwide such as the World Social Forum, the Americas Social Forum, the World March of Women, to mention just a few. A tangible outcome of this circulation of ideas is the Post-2015 Feminist Declaration, entitled 'Gender, Economic, Social and Ecological Justice for Sustainable Development', nurtured and signed by several collectives from Latin America and the Caribbean.

In forging this agenda, feminist and women's movements have not been alone. In fact, this thematic expansion is the fruitful result of a plethora of alliances and intermingling between these 
movements and other social 'mixed' movements. These latter are movements of contestation and resistance, comprising men and women, claiming social transformation and development justice. This is the case of indigenous movements, peasant and rural workers' movements, and environmental movements. These movements have nurtured the gender economic agenda and, in turn, they have integrated feminist claims within their frameworks. A case in point is Via Campesina (Peasant's Way), an international organisation whose Central American chapter has recently crafted its own 'Gender Strategy 2014/2018'. This fundamental document acknowledges that constructing a peasant world with food sovereignty, a fair distribution of land, the recognition of the value of peasant knowledge and skills, and a respect for biodiversity, are all transformations firmly entrenched with deep changes in the power relations governing the life of women and men. ${ }^{7}$ These are truly recursive advances, as feminists and activists on women's issues renew their own themes and ideas, and learn ideas from the progress of other movements, once gender becomes a claim in their discourses and collective actions.

Lastly, the saliency of the economic gender agenda varies by country, when we examine the domestic feminist agendas. For instance, in Brazil the entire economic gender agenda has more prominence than in Argentina, whose feminist agenda is mainly focused on sexual and reproductive rights. Paraguay has a clear mix of issues and one cannot be disentangled from another. Yet, beyond country specificities, this agenda envisioning an alternative mode of economic life is very welcome in the most unequal region of the world. Alarming figures show that despite a relatively wealthy decade and a decrease in poverty (from 45.5 per cent in 1999 to 32.7 per cent in 2012), the femininity index of poverty has increased from 108.1 per cent in 1999 to 117.2 per cent in 2012 on average in the region (ECLAC 2015).

\section{Conclusion}

The BPfA articulates six strategic objectives in the area of women and the economy. These objectives address crucial issues such as women's economic rights and access and control over resources, support for low-income women, the development of women's economic capacity and commercial networks, the removal of employment discrimination and segregation, and the harmonisation of work and family responsibilities. For the last 20 years, taken together, these objectives have provided a solid basis for feminist action in economic matters by supplying concrete lines of action as well as a political vocabulary for struggles dealing, mostly, with redistribution. The Latin American feminists we interviewed expressed their pride in the cognitive and discursive resources they have drawn from the BPfA on economic issues.

For employment and labour market issues, the region has many challenges ahead (Bianco and Winocur 2015). About 47.7 per cent of women are in precarious jobs in terms of salaries, social protection and welfare benefits, and basic rights. Discrimination in the labour market has not been eradicated and women's access to decent jobs is not guaranteed. For these issues, the BPfA provides a valuable cognitive and discursive tool to question, among other things, the scarce support that women face in the job market and in developing sustainable (micro) enterprises. The gender income gap and female poverty are issues on the feminist agenda.

Still, during the last 20 years, feminist actors have renewed their view of how the economy is a cause and a consequence of gender inequality. There is an increased recognition that economic processes are embedded in social and political structures of gender exploitation, subordination and control. A fairly compact feminist critique to development exists informing the gender economic agenda, which moves beyond the language of rights and redistributive demands alone. Certainly, indigenous, afro and rural women have helped broaden the debate on gender and the economy and, thus, expanded the agenda beyond the original six strategic objectives of the BPfA.

To summarise, access to resources and the removal of labour market androcentric biases in the structures of employment are important matters. But the agenda also addresses the very institutional foundations that justify transforming use value into exchange value at any cost, even putting the sustainability of life at risk. For this reason, feminists in the region are critical of how governments should promote development, foster productivity levels, and deal with macroeconomic dynamics. As civil organisations warn us in a recent regional report on Bejing+20 (Bianco and Winocur 2015), the ongoing development patterns should not rest upon the 'over exploitation of women, nor consider as comparative advantages the existing inequalities' (2015: 90). As a result of this perspective, in the new millennium, Latin American feminists mobilise around globalisation, economic crisis, uneven development projects and climate change. 


\section{Notes}

1 Final Declaration of the XIII Latin American and the Caribbean Encounter, Lima, Perú, 2014, http://13eflac.org/index.php/boletinas-listado.

2 Interview, October 2014.

3 This article draws upon ongoing research about the gender economic agenda in 18 Latin American countries. The empirical material was gathered systematically by means of a total of 70 in-depth interviews with different activists. This research is supported by the Gender Practice Area of the Regional Centre of the United Nations Programme for Development (UNDP/LACRO) and the Universidad Nacional de San Martín (UNSAM).

4 REMTE comprises collectives from Bolivia, Brazil, Chile, Ecuador, Mexico, Peru and Venezuela.

\section{References}

Bianco, M. and Winocur, M. (eds) (2015) A 20 años de la Plataforma de Acción de Beijing: Objetivos Estratégicos y Esferas de Preocupación. Documento Regional de la Sociedad Civil Beijing+20 América Latina y el Caribe, www.feim.org.ar/pdf/BEIJING+20-esp.pdf (accessed 12 May 2015)

Celiberti, L. and Vargas, V. (2003) 'Feministas en el Foro', Estudos Feministas 11.2: 586-98

CEPAL (2015) Informe Regional sobre el Examen y la Evaluación de la Declaración y la Plataforma de Acción de Beïing y el Documento Final del Vigesimotercer Período Extraordinario de Sesiones de la Asamblea General (2000) de los Países de América Latina y el Caribe, Santiago: CEPAL

Cumés, A. and Cu, M. (2012) 'Mujeres Indígenas, Género y Feminismos: Tendencias y Líneas de Pensamiento', unpublished manuscript

ECLAC (2015) '20 Years of Beijing Declaration and Platform for Action', Notes for Equality 16

Espino, A. (2012) 'La Dimension de Género de la Crisis Existe Una Agenda Feminista?', Nueva Sociedad 237: 87-98

Facio, A. (2007) Mujeres Descontentas con que el Gane del Si, www.radiofeminista.net/oct07/notas/gana_ si.htm (accessed 15 February 2015)

Fraser, N. (2000) 'Rethinking Redistribution', New Left Review 3: 107-20

Fraser, N. (1997) Fustice Interruptus: Critical Reflections on the 'Postsocialist' Condition, London: Routledge

Gargallo, F. (2009) 'El Feminismo y Su Instrumentalización como Fenómeno de
5 REPEM has nodes in Argentina, Bolivia, Brazil, Chile, Colombia, Costa Rica, Cuba, Ecuador, El Salvador, Guatemala, Honduras, Mexico, Nicaragua, Panama, Paraguay, Peru, the Dominican Republic, Uruguay and Venezuela.

6 This collective includes women's organisations from Mexico, Costa Rica, El Salvador, Guatemala, Honduras, Nicaragua and Panama.

7 See www.laviacampesina.hn/index.php/ programas/mujeres-campesinas/item/130dirigencia-campesina-socializa-estrategiay-politica-de-genero-de-la-via-campesinacentroamericana-2014-2018 (accessed 1 March 2015).

Mestizaje en Nuestramérica', Revista Venezolana de Estudios de la Mujer 14.33: 27-36

Martínez Franzoni, J. and Sánchez-Ancochea, D. (2014) 'The Double Challenge of Market and Social Incorporation: Progress and Bottlenecks in Latin America', Development Policy Review 32.3: 275-98

Molyneux, M. (1998) 'Analysing Women's

Movements', Development and Change 29.2: 219-45

Pérez Orozco, A. (2012) 'Prólogo', in V. Esquivel (ed.), La Economía Feminist Desde América Latina una Hoja de Ruta Sobre Los Debates Actuales en La Region, Santo Domingo: ONU Mujeres

Rousseau, S. (2011) 'Indigenous and Feminist Movements at the Constituent Assembly in Bolivia', Latin American Research Review 46.2: 5-28 Sagot, M. (2014) 'La Democracia en su Laberinto: El Neoliberalismo y Los Límites de La Acción Política Feminista en Centroamérica', in A. Carosio (ed.), Feminismos Para Un Cambio Civilizatorio, Caracas: CLACSO

Thompson, E.P. (1971) 'The Moral Economy of the English Crowd in the Eighteenth Century', Past and Present 50.1: 76-136

Torres, Tita (2013) 'El Camino Recorrido y Nuestro Pensamientos. Historia y Posicionamiento de las Mesoamericanas en Resistencia 2003-2013', unpublished presentation

Valdivieso, M. (2014) 'Otros Tiempos y Otros Feminismos en América Latina y el Caribe', in A. Carosio (ed.), Feminismos Para Un Cambio Civilizatorio, Caracas: CLACSO 